\title{
ORGUES I HARMÒNIUMS \\ DESTRUÏTS DURANT LA GUERRA CIVIL (1936-1939) A LES PARRÒQUIES DE LA DIÒCESI DE BARCELONA
}

\author{
Joan SERra SANMiquel \\ col-laborador de l'Arxiu Diocesà de Barcelona
}

J. M. Martí Bonet

director de l'Arxiu Diocesà de Barcelona

\begin{abstract}
With this article the Diocesan Archives in Barcelona wishes to participate on the occasion of the much deserved tribute paid to Canon Dr. Josep Pavia. We present a synopsis of the almost disastrous state of some 54 organs and 173 harmoniums, some of which were of great artistic and musical worth. We can but ask ourselves - why this state of affairs? We cannot fathom the reasons behind such disrepair. Surely the musical instruments are not to blame? May the present study contribute to a greater understanding of the history of our harmoniums and church organs.
\end{abstract}

\section{Resum}

Amb motiu del merescut homenatge que se li ofereix al canonge Dr. Josep Pavia, l’Arxiu Diocesà de Barcelona, vol col-laborar amb el present article. Aquest resum tracta de la quasi absoluta desfeta d'orgues —en nombre de cinquanta-quatre- i d'harmòniums -en nombre de cent setanta-tres-, alguns d'ells eren peces de gran interès artístico-musical. Hom sols es pregunta: "Perquè?"... No entenem els motius de tan gran destrucció. Quina culpa tenien aquests instruments musicals? L'article pot servir als investigadors de referent a la història dels nostres harmòniums i orgues.

\section{A tall d'introducció}

La destrucció d'instruments musicals de les nostres Parròquies durant la guerra civil, és molt important, tant quantitativa com qualitativament. La relació que figura en aquest treball s'ha extret del «Resum dels fets ocorreguts durant la Revolució de l'any 1936» i redactats pels respectius responsables parroquials. Actualment aquesta sèrie es conserva a l'Arxiu Diocesà de Barcelona, dins la sèrie Arranjaments Parroquials. Només, però, hi figuren aquelles Parròquies (dues-centes) de les que ens consten els lamentables fets ocorreguts, i sempre amb reserves. 
En un altre treball s'hauria d'investigar la importància musical, històrica i artística dels Orgues i Harmòniums relacionats. Però això ja representa una feina d'investigació que s'escapa de la finalitat que ens hem proposat. Fa feredat pensar amb el que ja no es recuperarà mai més,

Per passiva ens adonem de la importància de la substitució d'instruments musicals que fins avui s'ha dut a terme, encara que molt lentament. Per exemple les dues basíliques de Santa Maria del Pi i de Santa Maria del Mar de Barcelona no han pogut començar la seva recuperació en el que fa referència als orgues fins fa pocs anys (des del 1997) i amb campanyes que encara duren gràcies a l'entusiasme dels respectius rectors: Mn. Josep M. Vidal, Mn. Josep Llauradó, Mn. Albert Taulé i Mn. Francesc Tort. Tanmateix gràcies a Déu el poble cristià comença a gaudir de la música sacra pel culte i a l'ensems pot oferir a la societat en general un servei musical de primer ordre.

\title{
Elenc d'orgues i harmòniums destruïts
}

\author{
Parròquia del Bon Pastor, de Barcelona \\ Destruiit un Harmònium regular.
}

Parròquia de Betlem, de Barcelona

Un Orgue destruït. L'Harmònium no. Valor aproximat de l'Orgue: 130.000 pessetes.

Parròquia del Carme, de Barcelona

Un Orgue completament destruït. Valor aproximat: 35.000 pessetes.

Parròquia de la Mare de Déu dels Desemparats, de Barcelona

Harmònium i Piano totalment destruïts. Valor aproximat de l'Harmònium: 1.000 ptes.

Parròquia de la Mare de Déu dels Dolors, de Barcelona

L'Harmònium ha desaparegut. S'ignora si va ser destruït. Valor aproximat: 1.200 ptes.

Parròquia de la Mare de Déu de Lourdes, de Barcelona

Cremat un Harmònium valorat en 1.000 pessetes. I també un altre de més petit valorat en 400 pessetes. 
Orgues i Harmòniums destruïts durant la Guerra Civil (1936-1939) a les Parròquies de la Diòcesi de Barcelona

Parroquial Basílica de la Mare de Déu de la Mercè i de Sant Miquel Arcàngel, de Barcelona Dos Orgues destruïts.

Parròquia de la Mare de Déu de la Medalla Miraculosa, de Barcelona

Un Harmònium totalment destruit, valorat en 2.500 pessetes, preu de la seva compra d'ocasió.

Parròquia de la Mare de Déu de Montserrat, del Guinardó de Barcelona

Harmònium de registres, de veu potent i molt del gust dels músics, destruït. Valor aproximat: 1.500 pessetes.

Tinença Parroquial de la Mare de Déu del Port, de Barcelona

Harmònium totalment destruït. Valor unes 2.000 pessetes.

Parròquia de la Mare de Déu del Remei, de Les Corts de Barcelona

Orgue, Harmònium i Piano, destruïts. Valor aproximat unes 35.000 pessetes.

Parròquia de la Preciosíssima Sang de N. S. J., de Barcelona

Harmònium destruït. Valor aproximat: 1500 pessetes.

Parròquia de la Sagrada Família, de Barcelona. La Cripta

Orgue completament destruït. Valor aproximat: 30.000 pessetes.

Parròquia del Sagrat Cor de Jesús, de Barcelona

Harmònium destruït.

Parròquia de Sant Agustí, de Barcelona

Orgue destruït. Era del millor que hi havia. Comptava amb uns registres antics que els entesos deien que no podia haver-n'hi de millors.

Parròquia de Sant Andreu del Palomar, de Barcelona

Magnífic Orgue totalment cremat. Valor: 50.000 pessetes. Tres Harmòniums cremats o bé desapareguts. Valor: 10.000 pessetes. 
Parròquia de Sant Cugat, de Barcelona

Orgue i Harmònium destruïts. Valor aproximat: 40.000 pessetes.

Parròquia de Sant Francesc d'Assís, de Barcelona

Destruït un preciós Harmònium-Orgue. Valor: 4.000 pessetes.

Parròquia de Sant Francesc de Paula, de Barcelona

Incendiats i destruïts l'Orgue i l'Harmònium, de roure. Per la compra de l'Orgue s'hi destinaren 18.000 pessetes.

Parròquia de Sant Genís dels Agudells, de Barcelona

Destruïts dos Harmòniums. Valor: 1.400 pessetes.

Parròquia de Sant Jaume, de Barcelona

Destruïts totalment l'Orgue i tres Harmòniums. Valor aproximat: unes 60.000 pessetes.

Parròquia de Sant Jordi, de Vallcarca de Barcelona

Harmònium destruït. Valor aproximat: 2.000 pessetes.

Parròquia de Sant Josep, de Gràcia de Barcelona

Harmònium destruït.

Parròquia de Sant Joan, d'Horta de Barcelona

Harmònium destruït. Valor: 5.000 pessetes.

Parròquia de Sant Martí de Provençals, de Barcelona

Dos Harmòniums destruïts. Valor total aproximat: 2.000 pessetes.

Parròquia de Santa Engràcia, de Barcelona

L'Harmònium destruït per l'incendi. Valor aproximat: 7.000 pessetes. 
Parròquia de Sant Pacià, de Barcelona

Desapareguts dos Harmòniums. Valor aproximat: 3.000 pessetes.

Parròquia de Sant Pere de les Puel-les, de Barcelona

Cremats totalment l'Orgue i l'Harmònium. Valor aproximat: 70.000 pessetes.

Parròquia de Sant Miquel del Port, de Barcelona

Destruïts pel foc l'Orgue i l'Harmònium.

Parròquia de Sant Eulàlia de Vilapiscina, de Barcelona

Incendiat l'Harmònium. Valor aproximat: 10.000 pessetes. ("Era dels millors".)

Parròquia de Santa Madrona, de Barcelona

L'Orgue, de recent construcció, fou incendiat i destruït. Valor aproximat: 35.000 ptes.

Parròquia de Santa Maria de Gràcia (Jesús), de Barcelona

Cremat l'Orgue i un Harmònium, gran i bo. Valor aproximat de l'Orgue: 35.000 pessetes. Valor aproximat de l'Harmònium: 6.000 pessetes.

Parròquia de Santa Maria del Mar, de Barcelona

No consta documentació escrita de la destrucció de l'Orgue. Hi ha però, una fotografia que pertany a l'Orgue d'abans de la guerra, amb tota seguretat destruït.

Parròquia de Santa Maria del Pi, de Barcelona

L'Orgue va ser incendiat.

Parròquia de Sant Just i Sant Pastor, de Barcelona

Aquesta Parròquia, pel seu valor artístic, va ser protegida per la Generalitat i l'Orgue no va quedar gaire deteriorat.

Parròquia de Santa Maria de Sants, de Barcelona

Cremat l'Orgue. Valor aproximat: 75.000 pessetes. 
Parròquia de Santa Maria del Taulat, del Poble Nou de Barcelona

Harmònium destruït. Valor aproximat: 2.000 pessetes.

Parròquia de Santa Maria de Vallvidrera, de Barcelona

Dos Harmòniums destruïts, d'unes 1.500 pessetes cada un.

Parròquia de Santa Teresa de Jesús, de Barcelona

Destrossat un Harmònium. Valor aproximat de segona ma: 2.000 pessetes.

Parròquia de Jesucrist Redemptor, de Barcelona

Destruït l'Harmònium. Valor aproximat: 500 pessetes.

Parròquia del Sant Àngel Custodi, d'Hostafrancs de Barcelona

Orgue cremat completament. Valor aproximat: 50.000 pessetes.

Parròquia de la Mare de Déu de la Bonanova, de Barcelona

Orgue destruït, d'un valor aproximat de 30.000 pessetes.

Parròquia de Sant Salvador, de Cabrera d'Igualada

Harmònium destruït. Valor aproximat: 3.000 pessetes.

Parròquia de Sant Feliu, de Cabrera de Mar

Harmònium gran cremat. Valor aproximat: 2.000 pessetes.

Parròquia de la Santa Creu, de Cabrils

L'Orgue i l'Harmònium han quedat intactes.

Parròquia de Santa Maria, de Caldes de Montbui.

Tres Harmòniums cremats d'un valor total d'unes 7.500 pessetes. 
Parròquia de Sant Joan, de Campins.

Orgue totalment destruït, llançat daltabaix del Cor i fet a miques. Era bo i de força valor. I en bon estat.

Parròquia de Sant Fèlix, de Canovelles.

Harmònium cremat. Se'n van trobar algunes restes. Valor aproximat: 1.000 pessetes.

Parròquia de Sant Esteve, de Canyamars.

Es va salvar l'Harmònium, d'un valor d'unes 600 pessetes.

Parròquia de Santa Magadalena, de Canyelles

L'Harmònium va ser destruït i cremat. Valor aproximat: 2.000 pessetes.

Parròquia de Santa Maria, de Capellades

Orgue destruït. Dos Harmòniums destruïts, d'un valor aproximat de 1.000 pessetes l'un, i de 400 pessetes l'altra.

Parròquia de Santa Maria, del Bruc

Es va salvar l'Harmònium.

Parròquia de Sant Pere, de Bigues

L'Harmònium, bastant vell, es va conservar intacte.

Parròquia de Santa Maria de Barberà

Harmònium cremat. Valor aproximat: 2.000 pessetes.

Tinença Parroquial del Sant Crist de Canyet, de Badalona

Un magnífic Harmònium destruït, d'un valor de 5.000 pessetes.

Parròquia de Santa Maria, de Badalona

Orgue desaparegut. Valor aproximat: 50.000 pessetes. 
Parròquia de Sant Pere, d'Avinyonet

Harmònium cremat. Valor aproximat: 3.000 pessetes.

Parròquia de Sant Julià, d'Argentona

Incendiat l'Harmònium d'un valor aproximat de 2.000 pessetes.

Parròquia de Sant Genís, de l'Ametlla del Vallès

L'Harmònium no s'ha perdut, però s'ha de restaurar. Valor aproximat: 500 pessetes.

Parròquia de Santa Maria d'Almúnia, de Vilafranca del Penedès

Cremat l'Harmònium. Valor aproximat: 1.000 pessetes.

Parròquia de Sant Julià, d'Alfou

S'ha destruït l'Harmònium.

Parròquia de Sant Esteve, d'Alcoll

Es va salvar l'Harmònium.

Parròquia de Sant Pere, d'Abrera

Cremat l'Harmònium, d'un valor de 700 pessetes.

Parròquia de Santa Maria, de Cardedeu

Dos Harmòniums cremats, un d'ells de força valor. Valor aproximat del conjunt: 15.000 pessetes.

Parròquia de Sant Martí, de Carme

Cremat un Harmònium d'onze registres, nou i finíssim. De bona marca. Valor aproximat: 2000 pessetes.

Tinença Parroquial de Casa Aguilera, de Piera

Cremat un Harmònium petit. Valor aproximat 500 pessetes. 
Parròquia de Sant Esteve, de Castellar del Vallès

Destruït l'Orgue i un Harmònium. Valor aproximat: 100.000 pessetes.

Parròquia de Sant Vicenç, de Castellbisbal

Destruïts dos Harmòniums. Valor aproximat: 5000 pessetes.

Parròquia de Santa Maria, de Castelldefels

Destruït un Harmònium d'un valor aproximat de 2000 pessetes.

Parròquia de Sant Pere de Castellet, de Vilanova i La Geltrú

L'Harmònium es va salvar i acabada la guerra va passar a servir a la Parròquia de l'Arboç.

Parròquia de Sant Sadurní, de Castellví de la Marca

Destruït un Harmònium d'un valor aproximat de 3.000 pessetes.

Parròquia de Sant Miquel, de Castellví de Rosanes

Cremat un Harmònium.

Tinença Parroquial del Sagrat Cor de Jesús, de la Colònia Güell

Destruït l'Orgue. De procedència del Teatre Liceu de Barcelona. Valor aproximat: 50.000 pessetes.

Parròquia de Sant Corneli, de Collbató

S'ha conservat l'Harmònium.

Tinença Parroquial de Sant Antoni Abat, de Corbera de Llobregat

L'Harmònium va quedar en un estat deplorable. Valor aproximat: 400 pessetes.

Parròquia de Santa Maria, de Cornellà

Destruït un Harmònium. Valor aproximat: 3000 pessetes. 
Parròquia de Sant Esteve de la Costa, del Montseny

L'Harmònium s'ha recuperat.

Parròquia de Santa Maria, de Cubelles

Incendiat l'Harmònium d'un valor aproximat de 1.500 pessetes.

Parròquia de Sant Iscle i Victòria, de Dosrius

L'Harmònium es va conservar.

Parròquia de Santa Eulàlia, d'Esparreguera

Cremat l'Orgue, d'un gran valor, monumental. Valor aproximat: unes 200.000 pessetes.

Parròquia de Santa Magdalena, d'Esplugues de Llobregat

Destruit un petit Orgue, d'un valor aproximat de 15.000 pessetes.

Parròquia de Sant Salvador, d'Espoia

Cremat l'Harmònium, d'un valor aproximat de 500 pessetes.

Parròquia de Sant Cristòfol, de Fogars de Montclús

L'Harmònium es conserva, encara que en mal estat. Valor aproximat: 500 pessetes.

Parròquia de Santa Maria, de Foix derna.

L'Harmònium no va desaparèixer. Va passar a conservar-se a l'Església Parroquial mo-

Parròquia de Sant Pere i Sant Fèlix, de Fontrubí

Cremat l'Harmònium d'un valor aproximat de 500 pessetes.

Parròquia de Sant Pere, de Gornal

L'Harmònium ha desaparegut. Valor aproximat: 700 pessetes. 
Parròquia de Sant Esteve, de Granollers

Cremats l'Orgue i l'Harmònium. Valors aproximats: l'Orgue 30.000 pessetes, i l'Harmònium 2.500 pessetes.

Parròquia de Sant Vicenç, de Gualba

Es va salvar l'Harmònium.

Parròquia de Santa Maria de Bellver, de Guardiola de Font-rubí

Cremat l'Harmònium d'un valor aproximat de 5.000 pessetes.

Parròquia de Sant Salvador, de Les Gunyoles de Vilafranca del Penedès

Cremat l'Harmònium d'un valor aproximat de 5.000 pessetes.

Parròquia de la Mare de Déu de l'Esperança, de La Batllòria

Destruït l'Harmònium. Valor aproximat: 300 pessetes.

Parròquia de Sant Esteve, de La Garriga

Destruïts l'Orgue i dos Harmòniums, d'un valor total aproximat de 70.000 pessetes.

Parròquia de Sant Cristòfol, de La Granada

Cremat l'Harmònium, d'un valor aproximat de 400 pessetes.

Parròquia de Santa Maria, de La Llacuna

Destruït un Harmònium d'un valor aproximat de 1.000 pessetes.

Parròquia de Santa Maria, de La Palma de Cervelló

L'Harmònium, riquíssim, de l'any 1888, va ser cremat. Aquell any va costar aproximadament unes 2.500 pessetes.

Parròquia de Sant Valentí, de Les Cabanes. Vilafranca del Penedès.

Cremat l'Harmònium. 
Parròquia de Sant Andreu, de Llavaneres

Orgue i Harmònium destruïts. Valor aproximat de l'Orgue: 18.000 pessetes, i de l'Harmònium: 3.000 pessetes.

Parròquia de Santa Maria, de Llinars del Vallès

Destruït l'Harmònium.

Parròquia de Sant Cristòfol, de Lliçà de Vall

Es va salvar l'Harmònium de quatre jocs i mig. Valor aproximat: 7.000 pessetes.

Parròquia de Marganell, de Terrassa

L'Harmònium va ser destruït o bé cremat.

Parròquia de Santa Maria, de Martorell

Incendiat i destruït l'Orgue, valuós instrument del segle XVI. Barroc.

Parròquia de Santa Maria, de Martorelles

Es va salvar l'Harmònium.

Parròquia de Sant Pere, de Masnou

L'Harmònium va ser destruït.

Parròquia de Sant Pere, de Masquefa

Es va salvar l'Harmònium, que és important, i encara que deteriorat, s'ha aconseguit posar-lo en funcionament.

Parròquia de Santa Maria, de Mataró

De dos orgues van destruir el més antic. Valor aproximat: 100.000 pessetes.

Parròquia de Sant Joan i Sant Josep, de Mataró

Destruït l'Orgue. 
Parròquia de Santa Maria, de Miralles

Harmònium incendiat. Valor aproximat: 500 pessetes.

Parròquia de Sant Jaume, de Moià

Harmònium destruït totalment. Valor aproximat: 2.000 pessetes.

Parròquia de Molins de Rei

Dos Harmòniums i un Orgue destruïts. Valor aproximat dels dos Harmòniums: 10.000 pessetes. L'Orgue era força deteriorat.

Parròquia de Sant Joan, de Montgat

Destruït l'Harmònium. Valor aproximat: 1.300 pessetes.

Parròquia de Sant Pere, de Monistrol de Montserrat

Un magnífic Orgue totalment destruït. Era un dels més grans de tot Catalunya.

Parròquia de Santa Maria, de Montmeló

Harmònium destruït, de quatre teclats o registres, que era molt ben conservat. Valor aproximat: 2.000 pessetes.

Parròquia de Sant Sadurní, de Montornès

Cremat l'Harmònium. Valor aproximat: 500 pessetes.

Parròquia de Sant Julià, del Montseny

Harmònium destruït. Valor aproximat: 6.000 pessetes.

Parròquia de Sant Martí, de Mosqueroles

Harmònium que es conserva. D'escàs valor.

Parròquia de Sant Miquel, d'Olèrdola

Un Harmònium destruiit totalment. Valor aproximat: 4.000 pessetes. 
Parròquia de Sant Joan d'Olesa de Bonesvalls

«Hi havia un Harmònium dels millors i va ser totalment destruït. També va ser destruït l'Orgue. No queda clar si hi havia els dos instruments, o bé només un que anomena de diferent manera en cada una de les dues Relacions dels fets.»

\section{Parròquia d'Olesa de Montserrat}

Destruït l'antic Orgue, acabat de restaurar.

Parròquia de Sant Esteve, d'Olzinelles

L'Harmònium va ser deteriorat.

Parròquia de Sant Pau, de L'Ordal

L'Harmònium va ser destruït. Valor aproximat: 2.000 pessetes.

Parròquia de Sant Genís, de Palau de Plegamans

L'Harmònium va ser destruït el 14 d'agost de 1936. Se n'ha comprat un de nou.

\section{Parròquia de Sant Esteve, de Palautordera}

L'Harmònium, de gran potència, ha quedat inservible degut a grans desperfectes. La reparació costarà unes 5.000 pessetes.

\section{Parròquia de Santa Maria, de Palautordera}

L'Orgue i l'Harmònium van ser cremats. En una segona Relació dels fets es diu que l'Harmònium de l'Església Parroquial va ser salvat, i que l'Orgue, que ja era inservible, tenia una façana molt artística i de força mèrit.

Parròquia de Sant Julià, de Palou

L'Harmònium, força bo, va ser destruït. Valor aproximat: 1.100 pessetes.

Parròquia de Santa Eulàlia, de Pallejà

L'Harmònium va ser cremat. Valor aproximat: 2.000 pessetes. En una altra Relació dels fets es diu que l'Orgue va ser cremat. 
Parròquia de Santa Eulàlia de Mèrida, de Papiol

L'Harmònium va ser destruït. Un d'igual valia unes 15.000 pessetes.

Parròquia de Sant Esteve, de Parets del Vallès

L'Harmònium va ser totalment destruït. Valor aproximat: 2.500 pessetes.

Parròquia de Santa Maria, de Piera

L'Orgue i l'Harmònium van ser destruïts. Segons dades, el valor total aproximat era de 150.000 pessetes.

Parròquia de Sant Pere, d'Hostalets de Pierola

L'Harmònium ha quedat força deteriorat.

Parròquia de Santa Magdalena, del Pla del Penedès

Destruït i cremat l'Harmònium. Valor aproximat: 1.000 pessetes.

Parròquia de Sant Salvador, de Polinyà

Destruït l'Harmònium. Valor aproximat: 700 pessetes.

Parròquia de Santa Maria Magdalena, de Pontons pessetes.

L'Harmònium va ser llançat daltabaix del Cor i després cremat. Valor aproximat: 2.000

Parròquia de Sant Pere, de Premià

L'Harmònium va ser cremat.

Parròquia de Sant Cristòfol, de Premià

L'Harmònium totalment destruït. Valor aproximat unes 5.000 pessetes.

Parròquia de Sant Pere, de Riudebitlles

L'Harmònium va ser destruït. Valor aproximat unes 1.500 pessetes. 
Parròquia de Sant Esteve, de Ripollet

En una Relació dels fets es parla d'un Orgue destruït. I en una altra es diu que el valor era de 5.000 pessetes, cosa que fa pensar que es tractava d'un Harmònium.

Parròquia de Sant Pere, de Rubí

Va ser destruït un Orgue-Harmònium d'escàs valor, d'unes 5.000 pessetes.

Parròquia de Sant Fèlix, de Sabadell

Cremats l'Orgue i l'Harmònium. Valor aproximat: 40.000 pessetes.

Parròquia de la Puríssima Concepció, de Sabadell

El magnífic Orgue monumental va ser completament destruït. Va ser construït per la Casa J. Melcher \& Cía., de Bilbao, el 18 de desembre de 1921 . Valor aproximat 60.000 pessetes.

Parròquia de Sant Vicenç de les Jonqueres, de Sabadell

Destruït un Harmònium molt bo, d'unes 5.000 pessetes.

Parròquia de la Santíssima Trinitat, de Sabadell

Incendiat l'Harmònium. Unes 800 pessetes aproximades de valor.

Parròquia del Santíssim Salvador, de Sabadell

Va desaparèixer l'Harmònium. Valor aproximat: 4.000 pessetes.

Parròquia de la Mare de Déu de Gràcia, de Sabadell

L'Harmònium destruït, o millor dit, cremat. Valor aproximat: 3.000 pessetes. El 1946 es compra un nou Harmònium.

Parròquia de Sant Andreu de La Barca

Destruït un Harmònium de setze teclats. Valor aproximat: 3.000 pessetes.

Parròquia de Sant Boi de Llobregat

Destruït l'Orgue i l'Harmònium. Valor aproximat: 50.000 pessetes. 
Parròquia de Sant Martí, de Sant Celoni

Cremats l'Orgue i l'Harmònium, d'un valor total aproximat de 50.000 pessetes.

Parròquia de Sant Climent de Llobregat

L'Harmònium força destrossat. Arreglar-lo costarà unes 400 pessetes.

Parròquia de Sant Pere, de Sant Cugat del Vallès

L'Orgue s'ha conservat. L'Harmònium d'un valor aproximat de 7.000 pessetes, va ser cremat.

Parròquia de Santa Perpètua de la Mogoda

Destruït un Harmònium amb teclat. Valor aproximat unes 7.000 pessetes.

Parròquia de Santa Coloma de Cervelló

Va ser destruït l'Harmònium.

Parròquia de Sant Vicenç de Montalt

Es va salvar un Harmònium petit, però van destruir el gran i el van cremar. El seu valor era d'unes 10.000 pessetes.

Parròquia de Sant Vicenç dels Horts

No queda clar si el que es va destruir va ser un Orgue o un Harmònium. El seu valor era de 15.000 pessetes.

Parròquia de Sant Sadurní d'Anoia

Destruïts totalment l'Orgue i l'Harmònium. L'Orgue, construït el 1929, tenia un valor de 50.000 pessetes. I l'Harmònium, 5.000 pessetes.

Parròquia de Sant Quirze, de Terrassa

Destruït l'Harmònium.

Parròquia de Sant Martí, de Cerdanyola

L'Harmònium va ser cremat. Valor aproximat: 6.000 pessetes. 
Parròquia de Sentmenat

Destruït l'Harmònium. Valor aproximat: 1.000 pessetes.

Parròquia de Sant Bartomeu i Santa Tecla, de Sitges

L'Orgue destruït en la seva major part. Només s'ha conservat la caixa. Valor aproximat: unes 16.000 pessetes. L'Harmònium destruït.

Parròquia del Sant Esperit, de Terrassa

L'Orgue i quatre Harmòniums destruïts. Valor aproximat: 40.000 pessetes.

Parròquia de Sant Quintí de Mediona

Dos Harmòniums destruïts.

Parròquia de Sant Pere de Ribes

L'Harmònium gran va ser deteriorat, i el petit cremat. Valor aproximat: 5.500 pessetes.

Parròquia de Sant Pere de Molanta

Van cremar l'Harmònium. Valor aproximat: 500 pessetes.

Parròquia de Sant Martí Sarroca

L'Harmònium es va salvar.

Parròquia de Sant Just Desvern

Incendiats dos Harmòniums. El del Cor era d'un valor aproximat de 1.200 pessetes, i l'altra de 700 pessetes.

Parròquia de Sant Joan Despí

Cremat l'Harmònium. Valor unes 1.000 pessetes. En una altra relació de fets es parla, però, que va ser destruït l'Orgue.

Parròquia de Sant Jaume Ses-Oliveres

Es va salvar l'Harmònium.

Anuario Musical, 57 (2002) 
Parròquia de Sant Feliu del Racó

L'Harmònium fou destruït.

Parròquia de Sant Feliu de Llobregat

Destruït l'Harmònium.

Parròquia de Sant Fost de Campcentelles

Harmònium destruiit.

Parròquia de Sant Esteve Sesrovires

Destruïts dos Harmòniums. Valor aproximat unes 5.000 pessetes.

Parròquia de Sant Esteve de Cervelló

Dos Harmòniums destruïts. Un de 4.000 pessetes i l'altra de 250 pessetes.

Parròquia de Sant Llorenç dels Hortons

Destruït l'Harmònium.

Parròquia de Sant Pere, de Terrassa

L'Orgue va ser totalment destruït. Valor aproximat: 35.000 pessetes.

Parròquia de la Sagrada Família, de Terrassa

Van desaparèixer els dos Harmòniums que hi havia però se'n van recuperar uns altres.

Parròquia de Sant Josep, de Terrassa

L'Harmònium va ser cremat. Valor aproximat: 2.000 pessetes.

Parròquia de Sant Cebrià, de Tiana

Es va cremar l'Harmònium. Valor aproximat: 3.000 pessetes. 
Parròquia de Sant Joan, de La Torre de Claramunt

L'Harmònium va ser destruït. Valor aproximat unes 800 pessetes.

\section{Parròquia de Santa Maria i Sant Marçal de Torrelavid}

Els dos Harmòniums de les dues esglésies van ser cremats. Valor aproximat: 200 i 450 pessetes.

Parròquia de Sant Genís de Torrelles de Foix

L'Harmònium va ser llançat daltabaix del Cor i cremat. Valor aproximat: 2.000 pessetes.

Parròquia de Santa Maria d'Ullastrell

L'Harmònium destruït. Valor aproximat: 2.000 pessetes.

Parròquia de Sant Bartomeu, de Vallbona d'Anoia

Un Harmònium nou molt bo va ser totalment destruit. Valor aproximat: 3.000 pessetes.

Parròquia de Vallformosa de Vilobí

L'Harmònium va ser cremat. Valor aproximat: 2.000 pessetes.

Parròquia de Sant Andreu, de Vallgorguina

L'Harmònium no va desaparèixer sinó que es conserva en bon estat.

Parròquia de Sant Mateu, de Vallirana

L'Harmònium va ser destruït. Valor aproximat: 4.000 pessetes.

Parròquia de Sant Vicenç, de Vallromanes

L'Harmònium va ser cremat. Valor aproximat: 500 pessetes.

Parròquia de Sant Martí de Sorbet, de Viladecavalls

Va ser cremat l'Harmònium. Valor aproximat unes 5.000 pessetes. 
Parròquia de Santa Maria, de Vilafranca del Penedès

Orgue únic, amb consola del segle XVII. Destruït.

Parròquia de Sant Antoni, de Vilamajor setes.

L'Harmònium va ser incendiat al mateix temps que l'edifici. Valor aproximat: 1.500 pes-

Parròquia de Sant Esteve, de Vilanova de La Roca

L'Harmònium va desaparèixer. L'any 1914 va costar 500 pessetes.

Parròquia de Sant Joan, de Vilassar

L'Harmònium destruït, l'Orgue destruït en part i en part mal guardat. Valor aproximat de l'Orgue 52.000 pessetes.

Parròquia de Santa Maria de Villalba Sasserra

L'Harmònium cremat.

Parròquia de Sant Antoni Abat, de Vilanova i La Geltrú

Destruit totalment l'Orgue monumental. Valor aproximat unes 125.000 pessetes, sense tenir en compte el seu valor artístic.

Parròquia de Santa Maria, de La Geltrú

L'Orgue va ser totalment destruït.

\section{Reflexions conclusives}

Resumint el que hem exposat en aquesta relació, veiem que es van destruir cent setanta-tres Harmòniums i cinquanta-quatre Orgues. Es van salvar vint-i-dos Harmòniums i quatre Orgues.

Es fa difícil fixar el cost d'avui en dia de tot el que s'ha destrossat. Si tenim en compte els imports de l'any 1939, que a manera d'orientació donen els responsables de les Relacions de les destrosses, els assignem a cada un dels instruments, i hi apliquem l'augment que ha sofert el diner des de llavors, ens pot resultar una xifra d'onze mil milions de pessetes, o sia uns seixanta-sis milions d'euros. 
Fins després de seixanta anys després de la guerra civil o sigui fins l'any 2000, les estadístiques suara presentades eren considerades informacions "reservades" car es temia que podrien provocar reaccions contràries a la reconciliació desitjada i que tants esforços van costar a les persones pacificadors de la mateixa Església. Malgrat tot, avui dia creiem que fem un bé a la investigació publicant-les, sempre en el marc de la pacificació que cal conservar i augmentar. Tot i que la veritat mai ens ha de fer por: Per això no volem fer altre reflexió que la simple relació presentada, afegint que mai més s'han de produir uns fets tan lacerants que atemptaren a la cultura, religió i música del nostre poble. Mai més! 


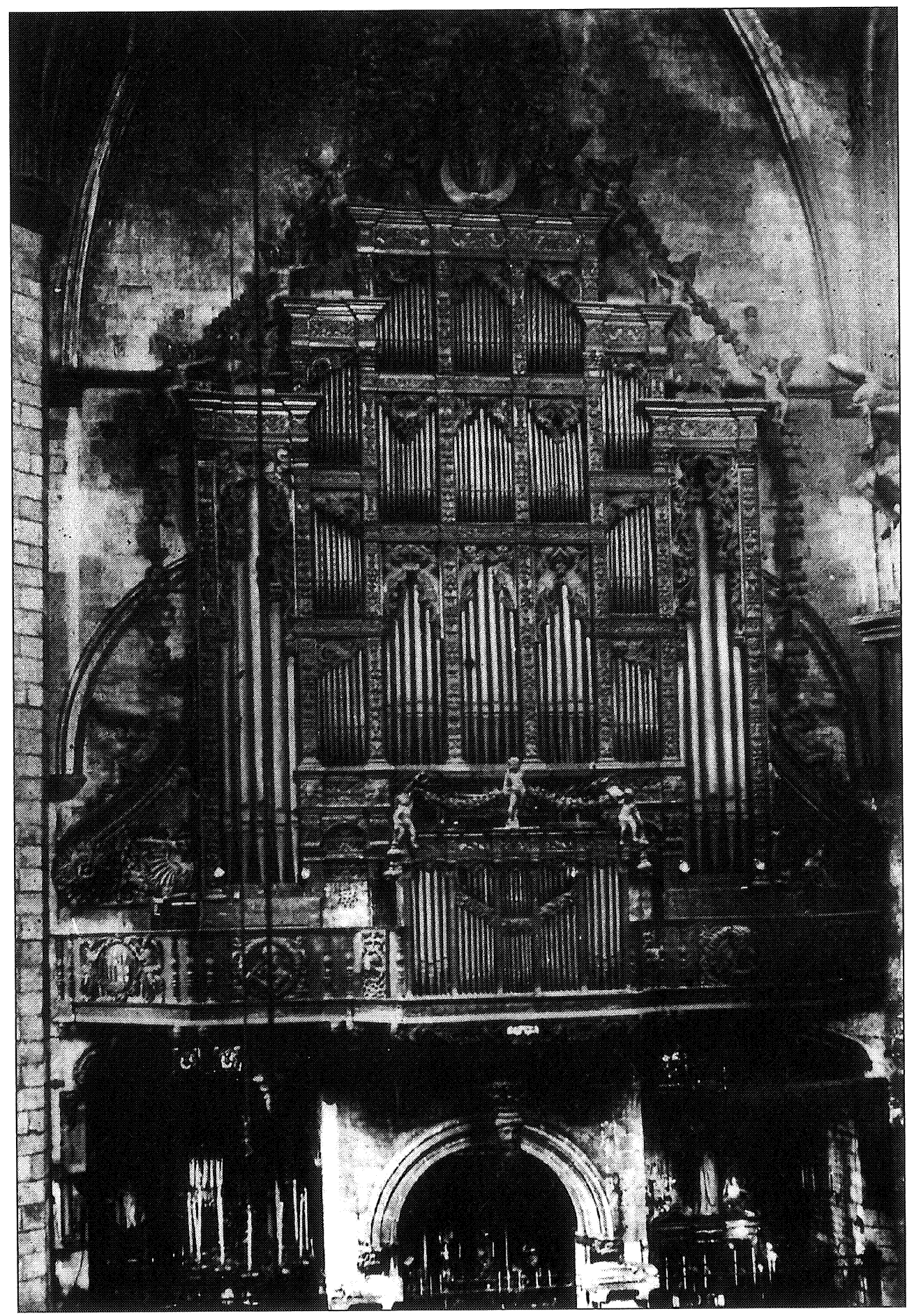

Santa Maria del Mar de Barcelona 


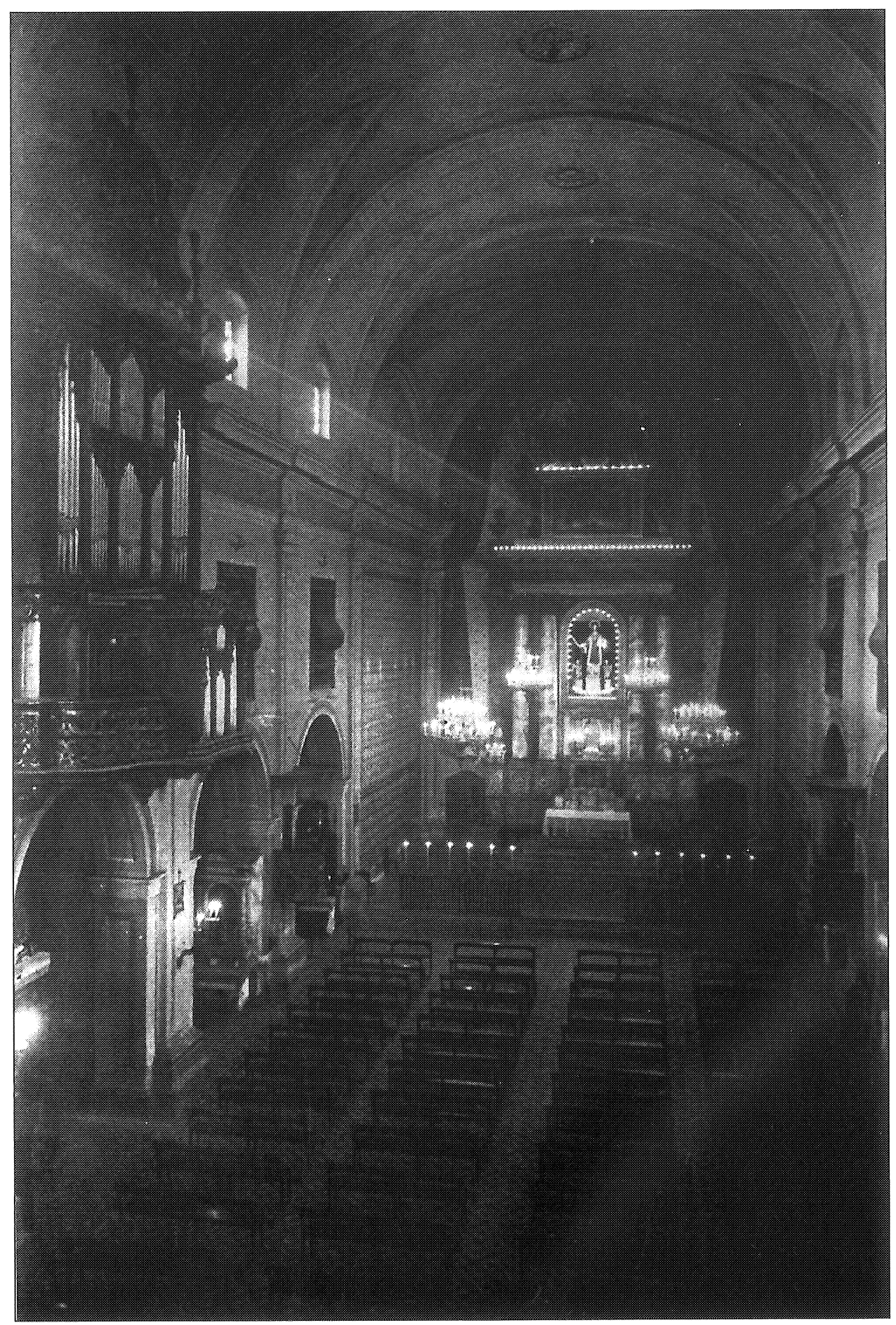

Sant Baudili de Sant Boi de Llobregat 


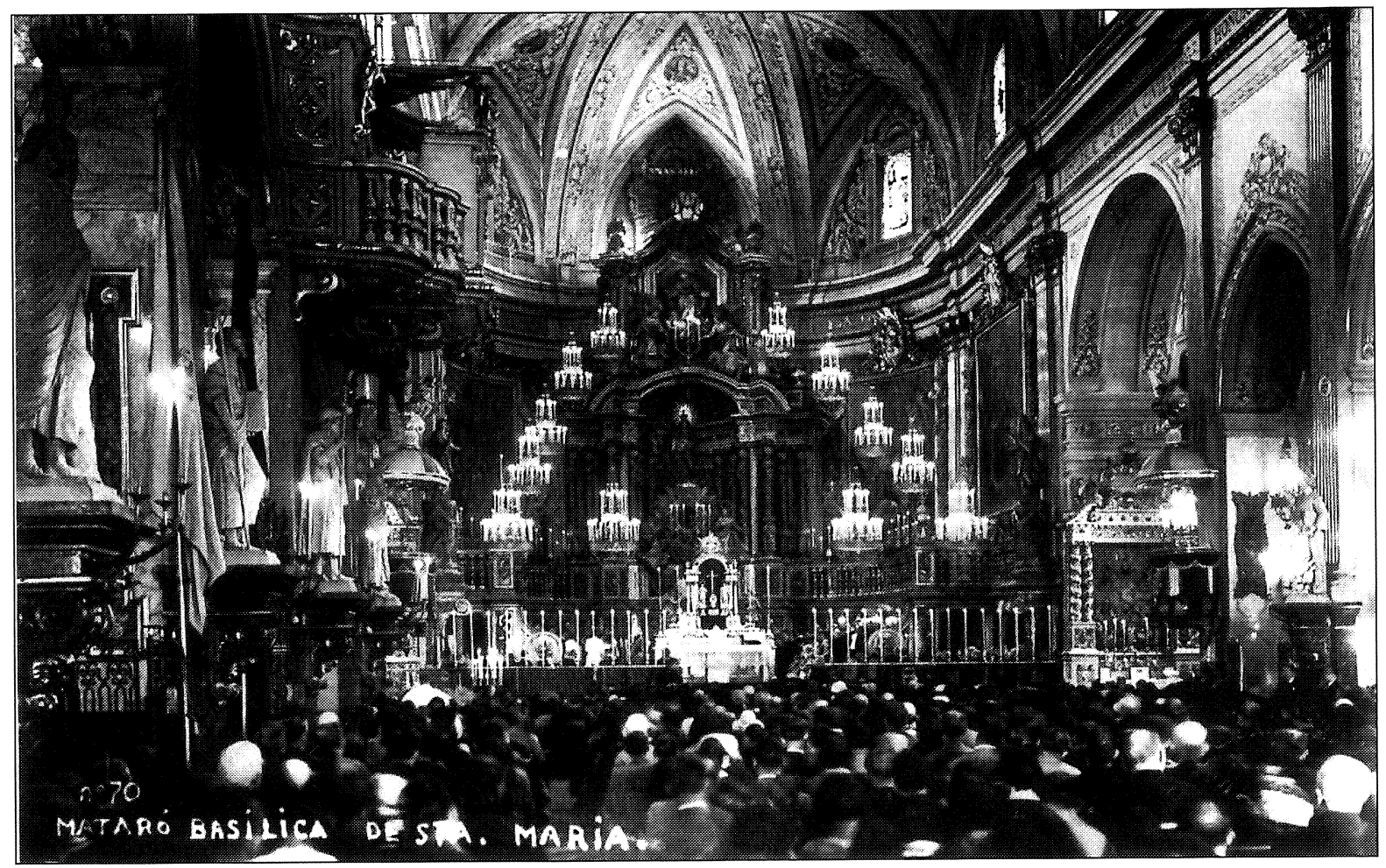

Basílica de Santa Maria de Mataró 